Ultrabasic dykes and veins

Post-dating all tectonic events are numerous ultrabasic dykes and veins up to $3 \mathrm{~m}$ in width, striking NW-SE or NE-SW. Many of these intrusions contain abundant rounded nodules and rounded xenocrysts of olivine or biotite. The rocks collected from this diatreme suite may include kimberlites.

\title{
References
}

Noe-Nygaard, A. \& Ramberg, H. 1961 : Geological reconnaissance map of the country between latitudes $69^{\circ} \mathrm{N}$ and $63^{\circ} 45 \mathrm{~N}$, West Greenland. Meddr Gronland 123, 5.

Windley, B. F. in press: Primary quartz ferro-dolerite/garnet amphibolite dykes in the Sukkertoppen region of West Greenland. Geol. $J$.

\section{QUATERNARY DEPOSITS BETWEEN THE SUKKERTOPPEN ICE CAP AND NORDRE STRØMFJORD}

\section{A. Weidick and N. W. Ten Brink}

The area investigated during 1969 is located approximately between $66^{\circ} 10^{\prime}$ and $67^{\circ} 30^{\prime} \mathrm{N}$, and $50^{\circ}$ and $52^{\circ} \mathrm{W}$, the eastern half of the West Greenland ice-free land area transected by Søndre Strømfjord. The principal objectives of the work were to map and describe the glacial and emerged marine deposits for a Quaternary map at 1:500 000 scale, and to collect material for establishing a radiometric chronology of former ice-margin positions and sea levels. In order to study as large an area as possible, the investigations north of Søndre Strømfjord and Sondrestrom Airbase were conducted by A. Weidick, the area south of this by N. W. Ten Brink.

The altitudes in the area decrease from the south (summits approximately 1300 $1500 \mathrm{~m}$ ) to the north (summits approximately $600 \mathrm{~m}$ ). The area is limited to the east by the present Inland Ice, to the south and west by the highlands of the Sukkertoppen and coastal Holsteinsborg districts, whereas to the north it extends into the lowlands around the inner branches of Nordre Strømfjord with maximum elevations rarely above $500 \mathrm{~m}$.

The present climatic conditions are extremely continental; the mean temperature at Sondrestrom Airbase for January is $-16^{\circ} \mathrm{C}$, for July $+10^{\circ} \mathrm{C}$, and for the year $-4.4^{\circ} \mathrm{C}$, with annual precipitation equal to $13-20 \mathrm{~cm}$ water equivalent. The existence of continuous permafrost throughout the area is therefore anticipated, and the results of various frost-action processes including patterned ground features are commonly 
observed. Sorted nets of extraordinarily large dimensions and coarse particle size (polygons $10-20 \mathrm{~m}$ in diameter, border stones $0.5-2 \mathrm{~m}$ in diameter) were observed above approximately 900-1000 $\mathrm{m}$ and near the orographic snowline of mid-August in the north-eastern part of the Sukkertoppen highlands. Active ice wedges and icevein networks were observed in frozen silt at two localities: near the inner part of Nordre Strømfjord under $0.5 \mathrm{~m}$ of peat, and in Sondrestrom Airbase under fill near the runway. Also in connection with the arid continental climate aeolian deposits (loess and dunes) are abundant, especially close to the Inland Ice margin and on emerged fluvial and marine deposits that form terraces along the rivers and large valleys. Deflation areas and ventifacts were observed locally; active deflation basins, often elongated into "wind flutings", were particularly noted $0-3 \mathrm{~km}$ from the ice margin south of Søndre Strømfjord.

Ground moraine is abundant in the larger east-west valleys, several of which cut through the western highlands and continue as fjords to the Davis Strait. Extensive moraine in the valleys and lowlands above marine limit displays a large variety of landforms: in addition to ice-margin features such as kame terraces, end moraines and proglacial drainage forms, the terrain also exhibits pitted outwash and kettled moraine, drumlinoid features, eskers and crevasse fillings.

Well developed ice-margin deposits, forming zones of kame terraces and/or end moraines, were mapped in several areas. All the ice-margin features were apparently formed by the Inland Ice, not by local glaciations, and detailed mapping during the 1969 summer, aided by study of recent aerial photographs, may enable regional correlation of the ice-margin deposits and the Holocene stages or substages which they represent. Various measurements of degree of weathering and soil development on the deposits were also obtained, and in some cases these measurements may facilitate approximate correlation.

Contacts between ice-margin deposits and former sea levels were observed at several places (Nordre Isortoq, Taserssuaq, Søndre Strømfjord, Umîvit). Dating of the former sea levels through radiocarbon analyses of shells and other organic material found in the emerged marine deposits should therefore supply an absolute chronology of Inland Ice margin positions associated with particular sea levels.

Several well developed marine shore lines have been formed by reworking of morainic deposits, and the regional extent of the uppermost shore line (100-110 m o. s. 1.) indicates that it must be the upper marine limit of the area. The uppermost 10-20 m of the marine deposits are mostly sandy gravel, and beach ridges often occur on the surfaces of terraces at this altitude. Only at two localities were shell-containing deposits encountered near the regional marine limit: in the one locality (Ilivigdlup tasia) only a few fragments occurred in sandy silt; in the other locality (east end of Taserssuaq) numerous shell fragments were found in concretions in laminated silt. Perched boulders at 110-120 $\mathrm{m}$ o. s. 1. near the west end of the lake Taserssuaq mentioned above also indicate that this level marks the marine limit.

The occurrence of a marine limit of $100-110 \mathrm{~m}$ seems to be restricted to areas 
west of $c .51^{\circ}$ longitude. East of this, the marine limit seems to be under $70-90 \mathrm{~m}$, but precise determination of the limit is complicated by interference with fluvial terraces and ice-margin deposits. Nonetheless, a moderately well developed 70-72 m strandline occurs along both the north and south shores of Umivit from $50^{\circ} 53^{\prime}$ to $51^{\circ} 03^{\prime} \mathrm{W}$. This strandline is shown to represent the marine limit by both a 73-75 $\mathrm{m}$ lower limit of perched boulders and a $60 \mathrm{~m}$ upper limit of sparsely fossiliferous, marine clay rich in organic material. The strandline is also clearly expressed as a wavecut terrace in morainic ice-margin deposits along the south-east shore of Umîvit and, therefore, indicates that the position of the ice-margin at this locality formerly corresponded to the $c .70 \mathrm{~m}$ sea level. A possibly significant ice-margin readvance is also suggested in this area by deformed and faulted marine deposits in which fragmented shells occur along fault planes. The boundary of change in marine limit at $51^{\circ} \mathrm{W}$ seems to coincide with the "fjord stages" of Weidick (1968).

For the lower marine deposits a transition in marine limit seems to occur around $50^{\circ} 30^{\prime}$ to $51^{\circ} \mathrm{W}$. West of this shell-rich layers, mostly in silts, occur up to $70-80 \mathrm{~m}$, whereas to the east the marine deposits are more sparse and occur only up to $40-50 \mathrm{~m}$. Their occurrence also seems to be restricted to certain valleys; although shell-bearing concretions in the southern branch of Nordre Strømfjord occur in marine silt that was pushed up to the frontal moraines of the Inland Ice in historical time, shells have not been found either in the laminated silt of the terraces in the inner part of Nordre Isortoq ("Isortoqelven") or in the valleys inside the inner branches of Søndre Strømfjord, where the eastern limit of fossiliferous deposits seems to be $50^{\circ} 30^{\prime} \mathrm{W}$.

\section{Reference}

Weidick, A. 1968: Observations on some Holocene glacier fluctuations in West Greenland. Bull. Gronlands geol. Unders. 73 (also Meddr Gronland 165, 6).

\section{THE NEW GGU BASE IN THE FISKENÆSSET AREA}

\section{G. Henderson}

During the summer the GGU base was moved from Mellembygden to north of Fiskenæsset. The new base, which has been given the name Midgård (old Norse the home of man), is situated at the mouth of a large river entering the sound Sarfat âriât, $16 \mathrm{~km}$ in a direct line north-north-east of the fishing village of Fiskenæsset. The journey by ship from Fiskenæsset to the base takes about two hours, the route lying either east or west of the large island of Qeqertarssuatsiaq. The main buildings are situated on the middle and largest of three terraces at the mouth of the river, and the camp area lies $20 \mathrm{~m}$ above sea level. 